\title{
Teacher's Teaching Strategies in EFL Class
}

\author{
Anrems Rafika Hayati \\ English Education Department, Institut Agama Islam Negeri (IAIN) Bengkulu \\ anremsrafikahayati105@gmail.com \\ Zelvia Liska Afriani \\ English Education Department, Institut Agama Islam Negeri (IAIN) Bengkulu \\ zelvia@iainbengkulu.ac.id \\ Ali Akbarjono \\ English Education Department, Institut Agama Islam Negeri (IAIN) Bengkulu \\ aliakbarj250975@gmail.com
}

\begin{abstract}
The purpose of this study was to analyze on how the implementation of teaching strategies used by English teacher and the reasons teacher used certain strategies for teaching in SMPN 20 Kota Bengkulu. The subject of this research is English teacher who taught at the first grade in SMPN 20 Kota Bengkulu. The researcher used Roy Killen's theory to analyze the teaching strategies used by English teacher. The theory of Roy Killen has nine teaching strategies that can be applied by English teacher in teaching and learning process in the classroom. There are direct instruction, discussion, small-group work, co-operative learning, problem solving, research, role play, case study, and writing. The research method used by the researcher was qualitative approach. The techniques of data collection were observation, interview, and documentation. The results of this research show that the teacher used some varieties of teaching strategies which are: direct instruction, discussion, small-group, and role play. The reasons teacher those strategies because those strategies made students more actively on follow the learning process, students could learn together and share their knowledge each other. The teacher used the same strategies for teaching English at first grade, but in term implementation of teaching strategies, the teacher still has difficulties to apply strategies in class during Covid-19 pandemic.
\end{abstract}

Keywords: Teacher, EFL, Teaching Strategies

\section{A. Introduction}

Teaching strategy is one of the supporting factors that will help the teacher process in the classroom. In the process of teaching and learning, the teaching strategy is important role. It can helps teacher to facilitates students' learning activities also it can be one of the ways used by teachers to make the teaching and 
learning process become more effective and interesting so that it will give significant effect to the students because they are learning by doing then the learning process activities in the classroom are not bored and the achievement of the learner's goals will be successful (Killen, 1998; Syafryadin, 2020). Teaching strategy is the approach that the teachers use for particular lesson and to the specific objectives for a particular lesson. It is necessary to be taken care that one strategy which is effective to be used in a certain material, might not be effective for another material.

In the process of learning English, the learning objectives desired by the teacher are usually not well-achieved and it gives impact to the students' achievement that is low. In fact, there are several factors influencing the process, namely the teacher who is still having difficulty in choosing suitable methods and strategies to use, and students who find it difficult to learn English because they are not familiar with foreign languages in their social communities. Nonetheless, the most prominent problem faced by the teacher is because each students are not the same as they have differences in terms of knowledge, abilities, and also learning styles between one student with another student to others. In addition, teachers also experience challenges in terms of teaching English at the youth level that will be more difficult than teaching English at the adult level. Because both of them have different characteristics.

The researcher did preliminary observation in SMPN 20 Kota Bengkulu. The researcher found several problems, namely, 1). Teachers are difficult to find strategies to practice in teaching English. 2). The teachers have difficulties to match strategies with English materials. 3). Teachers are hard to apply the strategies in the classroom. 4). Each student has different ability and knowledge. 5). Students have problems to understand English materials. 6). The values of students' are still low.

This study has three aims, such as: (1) to describe the teacher teaching strategies in EFL class at the first grade of SMP 20 Kota Bengkulu. (2) to know why does the teacher choose those strategies in EFL class at first grade of SMP 20 Kota 
Bengkulu. (3) to find and describe about the difficulties faced by English teacher in choosing a strategy in EFL class $t$ at first grade in SMPN 20 Kota Bengkulu.

\section{B. Literature Riview}

\section{Teaching Strategies}

Teaching strategy can be defined as a plan, method or series activities to achieve particular educational goal (Richards, Jack C. \& Rodgres. 1986). In addition teaching strategies are defined as the role taken by teacher or a teaching device such as computer, programed text, or television set in order to facilitate learning (Klein, M. Frances. 1991) Moreover teaching strategy is the approach that the teachers use for particular lesson and to the specific objectives for a particular lesson. It is necessary to be taken care that one strategy which is effective to be used in a certain material, might not be effective for another material (Roy Killen, 98). So that, the teaching strategy is an effort or method used by teachers to help teachers achieve their goals in carrying out the learning process based on the methods, efforts or methods, procedures used by teachers in making transfers they knowledge for the students. And also that teaching strategy can be said to be a plan or a series arrangement carried out by the teacher in learning so that learning can run effectively by using strategies in the process of delivering material to students.

A teacher is required to have pedagogy, strategy, and method competencies. For a learning process to be delivered more effectively, the teachers need a strategy to support the learning process, and the strategy plays an important role in creating more effective and active learning so that it makes students interested in learning. Therefore, the strategy is very important is owned and mastered by a teacher, and the strategy can also assist the teacher in the process of material to students. 


\section{Types of Teaching Strategies}

There are many kinds of teaching English strategies that can be applied in the language teaching process, According to Killen such as the teaching strategies as follow :

\section{a. Direct Instruction}

Direct instruction is a highly structured and teacher-centred and also direct instruction, as discussed previously, involves the direct transfer of knowledge from the teacher to a student, with the teacher doing most of the talking.

\section{b. Discussion}

Discussion can be used in any classroom environment by students to test their own ideas against those of other students. The teacher will facilitate the discussion and guide the discussion in the right direction if it strays.

\section{c. Small-group Work}

Small-group work is an activity that focuses on the students and the teacher should facilitate and give guidance to the different groups. The main goal is to produce evidence of their understanding. Small-group work can include a wide variety of activities. These activities can include small-group discussion, completing worksheets, solving problems or making presentations.

\section{d. Co-operative Learning}


Co-operative learning can take place within small groups or between two students working together. Students learn from each other and the teacher should pair students who will work effectively together.

\section{e. Problem Solving}

Problem-solving is a strategy that is widely used in classrooms. The students should solve the problem themselves using their prior knowledge to guide them towards a solution.

\section{f. Research}

Research can be used as a teaching strategy to promote self-learning and allow the students to discover new information on their own. Research can take the form of an investigation or guided research using materials such as books or the internet.

\section{g. Role Play}

This helps the students to solve problems and use the knowledge that they have acquired in a situation that resembles a real life situation. Role-play can help the students to understand information and to see its value.

\section{h. Case Study}

A case study can be combined with research, small-group work or cooperative learning. This strategy can be used to gather data in real-life situations and to analyze the data using problem-solving methods. This can help the students apply knowledge from the classroom and analyze data to present useful information. 


\section{i. Writing}

Writing is a good way of testing the students' knowledge and their understanding. It reveals their ability to write and tests whether they can relay information effectively. Through writing students can represent their opinions and also deal with problems that they might encounter in the classroom.

\section{Research Methodology}

In analyzing of teaching strategies used by English teacher at the first grade of SMPN 20 Kota Bengkulu. The researcher used qualitative research. Qualitative is used to investigate a problem in order to get a clear understanding of a certain phenomenon (Creswell, J.W. 1998). Besides, "qualitative research is focused on understanding the 'insiders' perspective' of people and their culture, and this requires direct personal and often participatory contact". So, the researcher will use qualitative method to get rich information and deeper understanding from participants' perspectives (Sugiyono. 2007). The researcher used observation, interview, and documentation to collected the data. The researcher took the data in SMPN 20 Kota Bengkulu. The subject of this study is teacher who taught at the first grade of SMPN 20 Kota Bengkulu. After collecting the data, the researcher analyzed the data used Miles and Hubermenn (1991) In short, the steps in analyzing the data are: (1) the researcher collects the data through observation and interview. Then, the researcher selects, identify, and focuses on the data by referring to formulation of the study. (2) After selected the data, the researcher displayed those data narrative essay. (3) After displaying data, the conclusion is drawn. Moreover, to get validity of data, the observation is supported by interview. Thus, the researcher will get conclusion of how the teaching strategies used by English teacher in teaching and learning process.

\section{Results and Discussion}

\section{Results}


adila: Journal of Development and Innovation

in Language and Literature Education

Publisher: Yayasan Karinosseff Muda Indonesia
E-ISSN: 2723-6900

P-ISSN: 2745-9578

Volume:. 1 Number 32021

Page: $330-341$

The discussion of the results has parts such as: first discuss about teaching strategies used by English Teacher in teaching learning English at First Grade in SMPN 20 Kota Bengkulu, second about the reason teacher choose those strategies in teaching learning English, and the last is the difficulties faced by English teacher in choosing a strategies in teaching English. In this research, the researcher used observation checklist, interview, and document to took the data. Teacher who taught at the first grade of SMPN 20 Kota Bengkulu used six of nine Killen's teaching strategies in teaching of EFL class at the first grade. The strategies were direct instruction, discussion, small- group, role play, problem solving, and co-operative learning.

The reasons of teacher used those strategies in EFL class at the first because teacher see the students' responses are more enthusiastic in participating in English learning, and the learning atmosphere is also more relaxed but the learning objectives are still achieved. And it can help the teacher to make it easier for students to understand the material that has been explained, for example with direct instruction strategy teacher could presents the materials by giving overview about the material, Discussion and small group strategies also helped students to learn respect between each students and they can share their opinion and role play strategy use because teacher can help students to increase new vocab and their practice to speak English.

The difficulties faced by English teacher in choosing a strategies in teaching English it found that the teacher experiences several difficulties, namely in terms still minimal supporting facilities and infrastructure, when the teacher wants to deliver material using interesting tricks or strategies it is constrained by supporting facilities, for example if the teacher want to use infocus sometimes other teachers use it too, sometimes the electricity have problem. Moreover, in the current conditions where people are experiencing Covid-19 pandemic, the learning system is carried out online. Many teachers have difficulties in carrying out the learning process, they want to do a zoom meeting learning system, but not all students come from families with good economies. Many students do not have a smartphone or laptop yet, so it can 
only be done online through the WhatsApp group, so the strategies used are also limited in carrying out the learning process.

\section{Discussion}

According to Killen (1996), teaching strategy is the approach that the teachers use for particular lesson and to the specific objectives for a particular lesson. It is necessary to be taken note that one strategy which is effective to be used in a certain material, might not be effective for another material. The result analysis showed that strategies which were used by English teacher in EFL class. In the learning process, the teacher plays an important role in achieving the success of the learning process. A teacher is required to have pedagogy, strategy, and method competencies. For a learning process to be delivered more effectively, the teachers need a strategy to support the learning process, and the strategy plays an important role in creating more effective and active learning so that it makes students interested in learning. In the process of teaching and learning, the strategy is very important because it can be one of the ways used by teachers to make the teaching and learning process become more effective and interesting so that, the achievement of the learner's goals will be successful. According Arvind, Kr Gill \& Kusum. (2017), teaching strategies and methods are one component in the learning system, inseparable from other components that are influenced by factors such as learning objectives, teaching materials, students, facilities, time, and teachers.

The result analysis showed that In SMPN 20 Kota Bengkulu at first grade, the teacher used sixth strategies based on finding of observation and interview did by researcher they are direct instruction, discussion, small-group, role play, co-operative learning, and problem solving. But the result of research did by the researcher, the teacher mostly used teaching strategies on teaching learning process such as ; direct instruction, discussion, small group, and role play. The reason of the teacher in choosing the strategy was due to several factors, namely the first teacher adjusted to the material first, the teacher also saw and read the situation and the student's level then why the teacher used this strategy because they see the students' responses are 
more enthusiastic in participating in English learning, and the learning atmosphere is also more relaxed but the learning objectives are still achieved. It can help the teacher to make it easier for students to understand the material that has been described. The difficulties faced by teacher in choosing teaching strategies are lack of supporting facilities and infrastructure vibes in implementing these strategies into the classroom in the constrained learning process.

\section{E. Conclusion}

Based on the result and discussion the conclusion teaching strategy is an effort or method used by teachers to help teachers achieve their goals in carrying out the learning process based on the methods, efforts or methods, procedures used by teachers in making transfers they knowledge for the students. And also that teaching strategy can be said to be a plan or a series arrangement carried out by the teacher in learning so that learning can run effectively by using strategies in the process of delivering material to students.

Teaching strategies used by the English teacher in teaching and learning process at first grade in SMP 20 Kota Bengkulu, to answer this research problem, the researcher used observation, interview, and documentation as a the technique of collecting data. The researcher found four types of teaching strategies used by English teacher in teaching and learning process. There are direct instruction, discussion, small group, and role play. Those strategies mostly used teacher to helping on teaching learning process in the class.

The reason why teacher used certain strategies because by using direct instruction they believed that the students would be easier to understand the materials that was explained by the direct under instruction by teacher rather than students should read the book by themselves because the teacher not only explain the materials but also give some examples relate with materials to students. So that, if students had understood the materials had taught by teacher it could be easy for students to 
continue to the next activities. These strategies can develop students to think critical analysis based on topic was given by the teacher. The difficulties in choosing and applying teaching strategies faced by English teacher are the supporting facilities and infrastructure which are still minimal in implementing these strategies into the classroom in the constrained learning process, the teacher is also still wondering what strategies are suitable for first-grade junior high school students because this junior high school class is still in transition from elementary to junior high school so that the students vocabularies are still low.

\section{References}

Arvind, Kr Gill \& Kusum. (2017). Teaching Approaches, Methods and Strategy. Scholarly Research Journal for Interdisciplinary Studies. 4(1), 2

Cohen, L., Manion, L., \& Morrison K. (2002). Research Methods in Education(5 ${ }^{\text {th }}$ Edition). London: Routledge Falmer.

Creswell, J. W.(1994). Research Design Qualitative and Quantitative Approaches. Sage Publications. London.

Creswell, J.W. (1998). Research Design: Qualitative, Quantitative and Mix Method Approaches (1sted). Thousand Oaks, CA: Sage Publication, Inc.

Creswell, J.W. Research Design: Qualitative, Quantitative and Mix Method Approaches (1sted). Thousand Oaks, CA: Sage Publication, Inc.

Creswell, J.W. (2012). Research Design Pendekatan Kualitatif, Kuantitatif, dan Mixed. Yogyakarta: Pustaka Pelajar.

Fitri, Yani (2016), Thesis: An Analysis Of Teachers' Strategies And Students' Different Learning Styles In English Teaching-Learning Process, State Islamic Institute Cirebon

Iurea, C., Neacsu, I., Safta, C. G., \& Suditu, M. (2011). The Study of the Relation between the Teaching Methods and the Learning Styles. The Impact upon Students' Academic Conduct. Procedia-Social and Behavioral Sciences, 11, 256-260. 
J.N. Ali \& H. Mina, 2014, Vol 3 Issue 5, The Important Role of Lesson Plan on Educational Achievement of IranianEFL Teachers' Attitudes, International Journal of Foreign Language Teaching \& Research.

Joyce, Bruce and weil, Marsha. (1996). Models of Teaching, Fifth Edition. Allyn \& Bacon, USA.

Kasiyan. (2015). Kesalahan Implementasi Teknik Triangulasi Pada Uji Validitas Data Skripsi Mahasiswa Jurusan Pendidikan Seni Rupa FBS UNY, imaji, Vol. 13, No. 1.

Killen, Roy (1996), Effective Teaching Strategies (Lesson from Research and Practice). Australia: Social Science Press.

Kvale, S. (1996). Interviews: An Introduction to Qualitative Research Interviewing. London: Sage Publications, Inc. 1996.

Lin, Chen, 2018, Vol. 1 I. 3, Teaching Strategies for Chinese Students to Study in English-Speaking Countries, International Journal for Cross-Discipli Subjects in Education (IJCDSE).

Mella Yossie English Teacher at First Grade at SMPN 20 Kota Bengkulu, Interviewed done on October, $3^{\text {rd }} 2019$, (Around 12.00 o'clock).

Miles, M, B., Huberman, M. (1994). Qualitative Data Analysis: an expanded sourcebook (2nd ed.). New Delhi: SAGE Publication.

Minimum Students Criteria of Mastery Learning (KKM) Data of Tenth Grade English Language Subjects at SMPN 20 Kota Bengkulu.

Preliminary observation the activities of learning English at SMPN 20 Kota Bengkulu, done on October, $3^{\text {rd }} 2019$, (Around 10.00 o'clock).

Ria. L, Muhammad. A \& Hefy. S, Thesis: The English Teaching Strategies For Young Learners In An International Primary School In Surakarta, Universitas Sebelas Maret

Richards, Jack C. \& Rodgres (1986), Approaches and Methods in Language Teaching, USA: Cambridge University Press. 1986

Robert J, Marzano. (2003). Classroom Management that works : Research- based strategies for every teacher. Virginia USA: Association for Supervision and Curriculum Development. 
adila: Journal of Development and Innovation

E-ISSN: 2723-6900

in Language and Literature Education

P-ISSN: 2745-9578

Publisher: Yayasan Karinosseff Muda Indonesia

Volume:. 1 Number 32021

Page: $330-341$

Setiyadi, B (2006), Teaching English as Foreign Language, Yogyakarta: Graha Ilmu.

Sugiyono. (2007). Metode Penelitian Pendidikan : Penelitian Kuantatife, Kualitatife, dan $R \& D$. Bandung. Alfabeta.

Sugiyono. (2014). Metode Penelitian Pendidikan Pendekatan Kuantitatif, Kualitatif, dan $R \& D$. Bandung: Alfabeta.

Suyanto, K.K.E (2008), English for Young Learners. Jakarta: Bumi Aksara.

Syafryadin, S. (2020). Students' Strategies in Learning Speaking: Experience of Two Indonesian Schools. Vision: Journal for Language and Foreign Language Learning, 9(1), 33-46.

Syafryadin, S., Martina, F., \& Salniwati, S. (2020). Compensation strategies in speaking activities for non-English department students: poor and competent speakers. JEES (Journal of English Educators Society), 5(2), 109-116.

Wena, M. (2013), Strategi Pembelajaran Inovatif Kontemporer. Jakarta: PT Bumi Aksara 